10 Cuellar AK, Johnson SL, Winters R. Distinctions between bipolar and unipolar depression. Clin Psychol Rev 2005; 25: 307-39.

11 Mitchell PB, Goodwin GM, Johnson G, Hirshfeld RM. Diagnostic guidelines for bipolar depression: a probabilistic approach. Bipolar Disord 2008; 10: 144-52.

12 Goodwin FK, Jamison KR. Manic-Depressive Illness: Bipolar Disorders and Recurrent Depression (2nd edn). Oxford University Press, 2007.

13 Ghaemi SN, Ko JY, Goodwin FK. Cade's disease and beyond: misdiagnosis, antidepressant use and a proposed definition for bipolar spectrum disorder. Can J Psychiatry 2002; 47: 125-34.

14 Hirshfeld RM, Lewis L, Vernik LA. Perceptions and impact of bipolar disorder: how far have we really come? Results of the National Depressive and ManicDepressive Association 2000 survey of individuals with bipolar disorder. J Clin Psychiatry 2003; 64: 161-74.

15 Ghaemi SN, Rosenquist KJ. Is insight in mania state-dependent? A metaanalysis. J Nerv Ment Dis 2004; 192: 771-5.

16 Jones I, Craddock N. Bipolar disorder and childbirth: the importance of recognising risk. Br J Psychiatry 2005; 186: 453-4.
17 Smith DJ, Ghaemi SN, Craddock N. The broad clinical spectrum of bipolar disorder: implications for research and practice. J Psychopharmacol 2008; 22: 397-400.

18 Sachs GS, Nierenberg AA, Calabrese JR, Marangell LB, Wisniewski SR, Gyulai $\mathrm{L}$, et al. Effectiveness of adjunctive antidepressant treatment for bipolar depression. N Engl J Med 2007; 356: 1711-22.

19 Horwitz AV, Wakefield JC. The Loss of Sadness: How Psychiatry Transformed Normal Sorrow into Depressive Disorder. Oxford University Press, 2007.

20 Rasmussen KG. Attempts to validate melancholic depression: some observations on modern research methodology. Bull Menninger Clin 2007; 71: 150-63

21 Owen MJ, Craddock N. Diagnosis of functional psychoses: time to face the future. Lancet 2009; 373: 190-1.

22 Insel TR. Rethinking schizophrenia. Nature 2010; 468: 187-93.

23 Craddock N, Antebi D, Attenburrow M-J, Bailey A, Carson A, Cowen P, et al. Wake-up call for British psychiatry. Br J Psychiatry 2008; 193: 6-9.

\title{
Yukio Mishima
}

\section{Martin Humphreys, Henry Scott Stokes}

Kimitake Hiraoke was born in Tokyo in January 1925. As Yukio Mishima, the pen name he used from the age of 16, when his first work was published, he became, and still remains, the best known Japanese author in the West and worldwide. He was a prolific writer to the time of his death in 1970, at the age of 45 . He produced books, poetry, plays and short stories. He wrote with great scope and sensitivity, and a disturbing frankness and honesty about himself, revealing for instance, many aspects of his personality and sexuality in Confessions of a Mask. He was at one time thought to be a future winner of the Nobel Prize for literature. He became a film star. Yet he was a man of contradictions and contrasts.

Mishima was born into a good family. His paternal grandfather had been a provincial governor and his grandmother was descended from Samurai. It was this grandmother who, soon after his birth, removed her grandson from his mother, insisting that he remain always with her, despite her own failing health and throughout her terminal illness, his life being more that of a girl than a boy. Mishima was frail and suffered his own serious illness in childhood. No underlying cause was identified. Later he would take up physical pursuits, in particular body building, at a time when it was not fashionable. He was quiet and obedient in early years and experienced difficulty in social settings as a young man. In adulthood he was often gregarious, lively and good humoured. He was self-conscious and narcissistic but could also be brooding and paranoid. He had a life-long fear of being poisoned. And yet he had a flow of great energy. And he operated a policy of total openness meaning that he and his work are there for all still to see.

From a young age Mishima became aware of death and was gripped by it. He read about it and indulged in fantasies around it, imbuing it with a sense of excitement, beauty and nobility. He came to be almost obsessed with the end of his own life. But he lived through the chaos of the Second World War and witnessed the bombing of Tokyo, describing later how he feigned symptoms at an army medical to avoid military service. He was homosexual but married and made a family life. He was capable of espousing non-Japanese ways and values, building a large Western-style house in the capital and travelling extensively. Yet he remained fiercely aware of his country's heritage and what he considered it's hidden, darker, core. After a brilliant school career, Mishima dutifully commenced work in government service, though he continued to write and seek out the company of other writers and intellectuals, and seems to have been relentless in his pursuit of fame. But he was hugely disciplined. And he became convinced that Japan was in some way cursed and needed to restore its position as a country and in the world. He formed a private army. He aspired to the old way of literature and the sword. He completed the tetralogy, The Sea of Fertility, immediately before his death. On 25 November 1970 he attempted to incite a military coup but failed. With one of four student members of his Tatenokai with whom he had earlier kidnapped a serving general, Yukio Mishima committed ritual suicide by disembowelling, a companion then beheading him.

Martin Humpheys is senior lecturer in forensic psychiatry at the University of Birmingham and Henry Scott Stokes is an author, journalist and biographer of Yukio Mishima. 